\title{
False Positive F-I8 FDG PET/CT of Skeletal Metastasis Due to Solitary Eosinophilic Granuloma
}

\author{
Iskelet Metastazında Soliter Eozinofilik Granüloma Bağlı Yanlış Pozitif F- 8 FDG PET/CT \\ Robert Mansberg1, Bao Ho1, Chuong Buil, Cathie Crombie2 \\ INepean Hospital, Nuclear Medicine and PET, Penrith, Australia \\ 2Nepean Hospital, Oncology Department, Penrith, Australia
}

\begin{abstract}
A 31 year old female with a 3 month history of focal right mid posterior thoracic pain, and solitary lytic lesion in the right $7^{\text {th }}$ rib posteriorly on bone scan (SPECT/CT) was referred for PET/CT to identify alternate site for biopsy in suspected malignancy. The patient had no significant past medical history and was afebrile with mildly elevated inflammatory markers. A solitary intensely FDG avid focus was demonstrated localised to a well-defined lytic lesion with partial cortical erosion on the posterior aspect of the right $7^{\text {th }}$ rib. No adjacent soft tissue abnormality was seen. No other site of biopsy was demonstrated. As malignancy (metastatic or primary) was not excluded, CT guided localisation with hookwire and blue dye injection was performed immediately prior to partial resection of the right $7^{\text {th }}$ rib. Histopathology confirmed the diagnosis of eosinophilic granuloma.
\end{abstract}

Key words: Positron Emission Tomography /computed tomography, Fluorodeoxyglucose F18, Eosinophilic granuloma, image-guided surgery

\begin{abstract}
Özet
Fokal sağ orta-posterior göğüs ağrısı ve kemik sintigrafisinde (SPECT/CT) sağ 7. Kosta posteriorunda soliter litik lezyonu olan 31 yaşında kadın hasta, malignite şüphesiyle alternatif biyopsi bölgesi tanımlanması amacıyla PET/CT için refere edildi. Hastanın tıbbi geçmişinde önemli bir bulgu yoktu ve hafif artmış enflamatuar markerların yanı sıra ateşi yoktu. Sağ 7. kostanın posteriorunda, kısmi kortikal erozyon gösteren belirgin litik lezyona lokalize yoğun soliter FDG tutulumu görüldü. 7 kaburga. Hiçbir komşu yumuşak doku anormalliği görülmedi. Biyopsi için başka hiçbir bölge tanımlanamadı. Malignite (metastatik veya primer) ekarte edilmediği içinhookwire ile CT rehberliğinde lokalizasyon ve mavi boya enjeksiyonu sonrasında sağ 7. kostanın kısmi rezeksiyonu yapıldı. Histopatoloji, Eozinofilik Granülom tanısını doğrulandı.
\end{abstract}

Anahtar kelimeler: Pozitron Emisyon Tomografi/Bilgisayarlı Tomografi, Florodeoksiglukoz F18, Eozinofilik granülom, görüntü kılavuzluğunda cerrahi

\section{Introduction}

Eosinophilic Granuloma (Histiocytosis $X$ ) is the benign form of the clinical variants of Langerhans cell histiocytosis and characterized by single or multiple skeletal lesions predominantly in children, adolescents and young adults 1 . We report a 31 year old woman who presented to her local doctor with severe pain in the right posterior thoracic region. A solitary lytic lesion was demonstrated in the right 7th rib posteriorly on bone scan (SPECT/CT) and subsequently on PET/CT. As no alternative site for biopsy was revealed accurate localisation of the lesion with $\mathrm{CT}$ guided hookwire positioning and blue dye injection was performed prior to excision biopsy. Histopathology confirmed the lesion to be due to solitary eosinophilic granuloma.

\section{Case Report}

A 31 year old female presented with a three month history of right mid posterior thoracic pain. A bone scan with

Address for Correspondence: Robert Mansberg MD, Nepean Hospital, Nuclear Medicine and PET, Penrith, Australia

Phone: 6147342156 E-mail: mansberg@usyd.edu.au Received: March 01, 2012 Accepted: April 01, 2012 
SPECT/CT was performed following the administration of 750 MBq Technetium 99m MDP on a GE Hawkeye Gamma Camera. A solitary focus of intense osteoblastic activity was demonstrated in the right 7th rib posteriorly (Solid black arrow ) on planar and SPECT (Solid white arrow) on axial CT slice (Figure 1).

The patient was referred for a FDG PET/CT study to assess for alternate sites for tissue biopsy in suspected malignancy. A FDG PET study and low dose CT study was
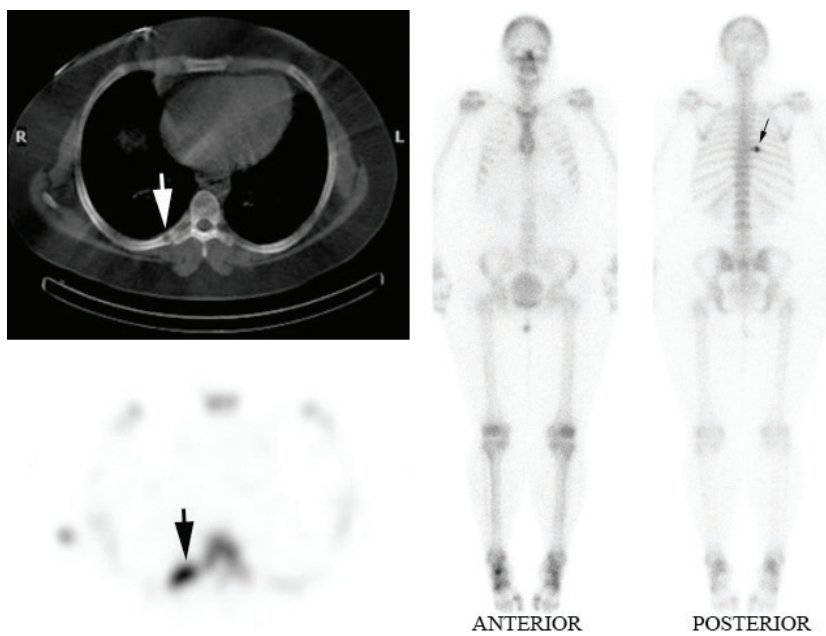

Figure 1. A solitary focus of intense osteoblastic activity demonstrated in the right $7^{\text {th }}$ rib posteriorly (Solid black arrow) on planar and SPECT images and (Solid white arrow) on axial CT slice
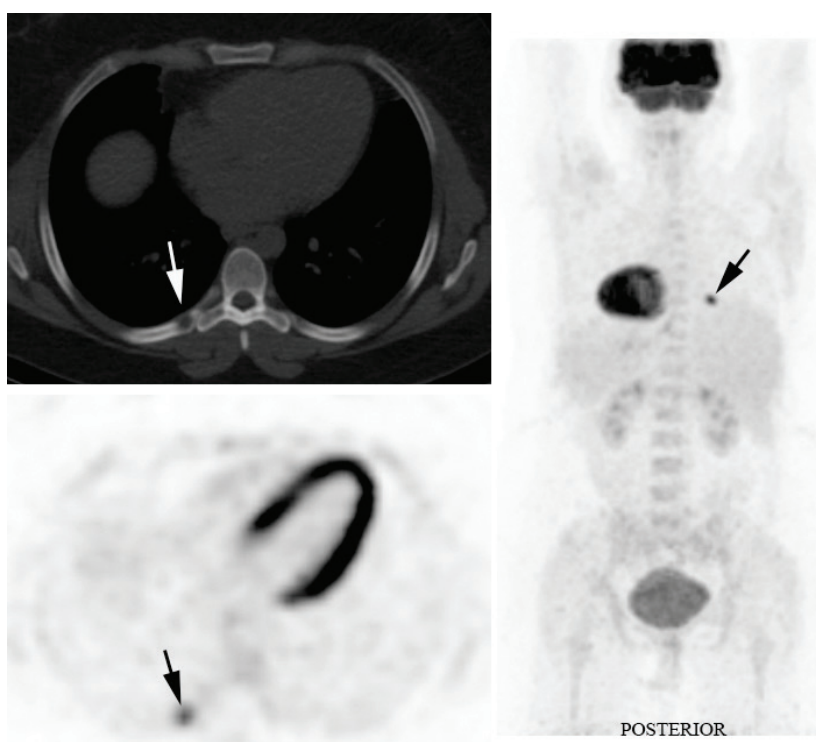

Figure 2. The PET study revealed a solitary focal intense FDG uptake in the right $7^{\text {th }}$ rib posteriorly (solid black arrow). The concurrent low dose $\mathrm{CT}$ scan of the Philips Gemini 64 PET/CT camera confirmed the presence of a well-defined lytic lesion with partial bony erosion at the site of the intensely increased FDG uptake (solid white arrow) performed following administration of $240 \mathrm{MBq}$ F18 FDG on a Philips Gemini 64 PET/CT camera. The PET study revealed a solitary focal intense FDG uptake in the right 7th rib posteriorly (solid black arrow). The concurrent low dose CT scan of the Philips Gemini 64 PET/CT camera confirmed the presence of a well-defined lytic lesion with partial bony erosion at the site of the intensely increased FDG uptake (solid white arrow) (Figure 2).

In the absence of an alternate site for biopsy the patient underwent $\mathrm{CT}$ guided hookwire localization and injection of blue dye prior to an excision biopsy of the lesion (solid white arrow Figure 3). The gross specimen of the resected right 7th rib lesion revealed a friable tan tissue with flecks of yellow. Microscopically an infiltrate of histiocytes, sheets of Langerhan's cells and inflammatory cells were present, confirming the diagnosis of eosinophilic granuloma.

\section{Literature Review and Discussion}

Eosinophilic granuloma is a benign form of the three clinical variants of Langerhans cell histiocytosis. It is characterized by single or multiple skeletal or lung lesions, and it predominantly affects children, adolescents, and young adults. Solitary lesions are more common than multiple lesions. There is a two to one male preponderance.

In skeletal involvement, eosinophilic granuloma can be asymptomatic or present with local pain, swelling and tenderness and ESR may be elevated. The lesion may cause endosteal scalloping or a periosteal reaction (1).

PET with F18-FDG is recommended for the primary diagnosis and staging as well as for the detection of recurrences in patients with different types of tumor. However, conventional radiography is still the method of

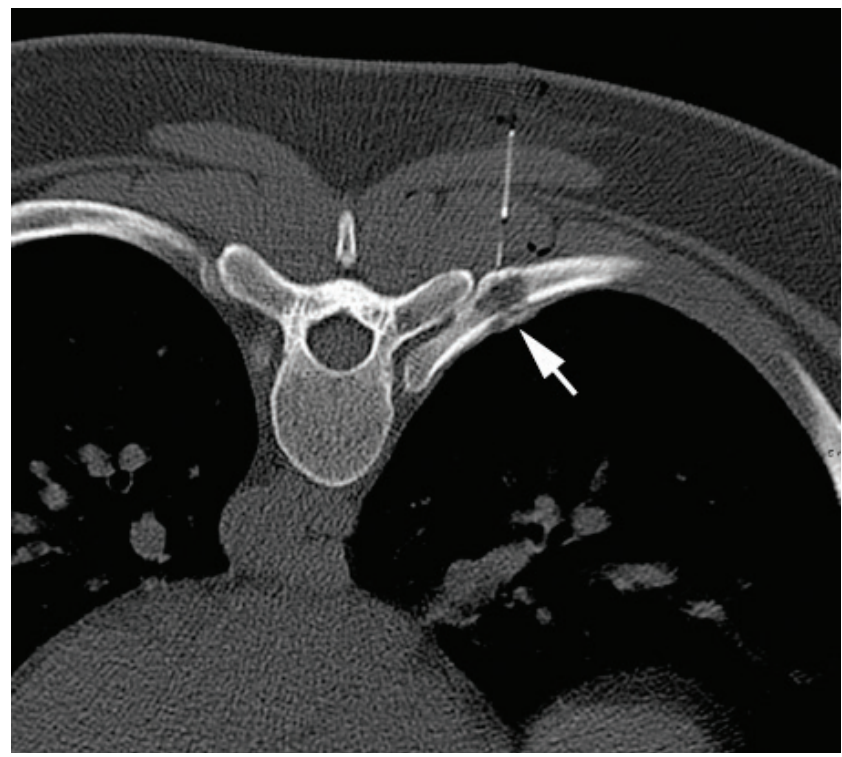

Figure 3. CT guided hookwire localization and injection of blue dye prior to an excision biopsy of the lesion (solid white arrow) 
choice for the initial diagnosis of a primary bone tumor and the differentiation between malignant and benign intraosseous lesions. In many cases, CT and MRI are needed to assess the nature and the morphology of a suspicious lesion. However, the sensitivity and specificity of CT and MRI may be highly variable. Bone scan is highly sensitive but is also not specific $(2,3,4)$.

The sensitivity reported in the literature for PET scanner exceeds $90 \%$, whereas the specificity also remains lower and highly variable, ranging from $65 \%$ to $80 \%(2,5,8)$. Low-grade tumors, which frequently show a low F18-FDG uptake, provide the main reason for false-negative results. False-positive results may be caused not only by acute inflammatory lesions but also by some benign diseases with an inflammatory component, such as eosinophilic granuloma, fibrous dysplasia, or aneurysmal cysts $(6,8,9,10,11)$.

This case highlights eosinophilic granuloma as a potential interpretative pitfall demonstrating that FDG uptake is not specific for malignancy. Many different physiological variants and benign pathological conditions can also exhibit increased glucose metabolism. Such false-positive FDG uptake often arises outside the area of primary interest and may mimic malignant disease, thereby confounding accurate interpretation of PET/CT studies.

\section{References}

1. Gersten T. Histiocytosis, Online Referencing http://www.ncbi.nlm. nih.gov/pubmedhealth/PMH0001133/ (2010 Accessed March 2012)
2. Dimitrakopoulou-Strauss A, Strauss LG, Heichel T, Wu H, Burger $C$ Bernd L, Ewerbeck V. The Role of Quantitative 18F-FDG PET Studies for the Differentiation of Malignant and Benign Bone Lesions. J Nucl Med 2002;4:510-518.

3. Brig SS Anand, Lt Col H Singh, Wg Dash. Clinical Applications of PET and PET-CT. MJAFI 2009;65:353-358.

4. Kern KA, Brunetti A, Norton JA, Chang AE, Malawer M, Lack E, Finn RD, Rosenberg SA, Larson SM. Metabolic imaging of human extremity musculoskeletal tumors by PET. J Nucl Med 1988;29:181186.

5. Culverwell A.D, Scarsbrook A.F, Chowdhury F.U. False-positive uptake on 2-[18F]-fluoro-2-deoxy-D-glucose (FDG) positron-emission tomography/computed tomography (PET/CT) in oncological imaging. Clinical Radiology 2011:366-382.

6. Aoki J, Watanabe H, Shinozaki T, Takagishi K, Ishijima H, Oya N, Sato $\mathrm{N}$, Inoue T, Endo K. 18FDG PET of primary benign and malignant bone tumors: standardized uptake value in 52 lesions. Radiology 2001;219:774-777

7. Khurana A, Jaimini A, Tripathi M, Mondal A. Benign bone cyst mimicking skeletal metastasis on 18F-FDG-PET. Hell J Nucl Med 2009;12:179-180.

8. Strauss LG. Fluorine-18 deoxyglucose and false-positive results: a major problem in the diagnostics of oncological patients. Eur J Nucl Med 1998;23:1409-1415.

9. Schulte Michael, Krauss DB, Heymer B, Guhlmann A, Hartwig E, Sarkar MR, Diederichs CG, Baer AV, Kotzerke J, Reske SN. Grading of tumors and tumor like lesions of the bone: Evaluation by 18F-FDG PET. J Nucl Med 2000;41:1696-1701.

10. Dehdashti F, Siegel BA, Griffeth LK, Fusselman MJ, Trask DD, McGuire AH, McGuire DJ. Benign versus malignant intraosseous lesions: discrimination by means of PET with 2-(F-18)fluoro-2-deoxyD-glucose. Radiology 1996;200:243-247.

11. Naumann $R$, Beuthien-Baumann $B$, Fischer $R$, Kittner $T$, Bredow J, Kropp J, Ockert D, Ehninger G. Simultaneous occurrence of Hodgkin's lymphoma and eosinophilic granuloma: a potentia pitfall in positron emission tomography imaging. Clin Lymphoma 2002;3:121-124. 